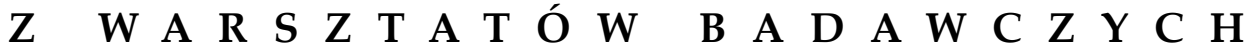

PRZEGLĄD BIBLIOTECZNY 2019 z. 2

PL ISSN 0033-202X

NATALIA BIAŁKA

Uniwersytet Jagielloński w Krakowie

e-mail: natalia2.bialka@doctoral.uj.edu.pl

\section{OBECNOŚĆ PRZEDSTAWICIELI POLSKIEJ INFORMATOLOGII I BIBLIOLOGII W SERWISACH SPOŁECZNOŚCIOWYCH DLA NAUKOWCÓW ACADEMIA.EDU I RESEARCHGATE}

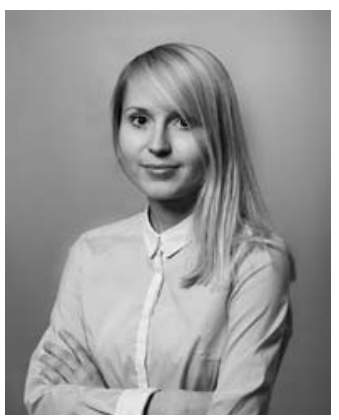

Natalia Białka, absolwentka informacji naukowej i bibliotekoznawstwa oraz historii Uniwersytetu Jagiellońskiego, doktorantka na Wydziale Zarządzania i Komunikacji Społecznej Uniwersytetu Jagiellońskiego. Database Coordinator w wydawnictwie De Gruyter. Jej obecne zainteresowania naukowe koncentrują się wokół drapieżnego publikowania w komunikacji naukowej.

SŁOWA KLUCZOWE: Academia.edu. Informatologia i bibliologia w Polsce. ResearchGate. Media społecznościowe dla naukowców.

ABSTRAKT: Teza/Cel - Celem artykułu jest przedstawienie obecności grupy polskich specjalistów z zakresu informatologii i bibliologii w serwisach Academia.edu i ResearchGate oraz określenie jej struktury według wieku, płci, wykształcenia, zajmowanego stanowiska i zainteresowań badawczych. W kontekście tego badania słowo 'obecność' jest rozumiane jako założenie konta, niezależnie od formy i stopnia zaangażowania w działania prowadzone w jego obrębie. Metody - Zgodnie z założoną metodyką wyszukiwania kont pracowników naukowych z dziedziny informatologii i bibliologii w portalach Academia.edu i ResearchGate została stworzona baza danych zawierająca informacje na temat zmiennych wieku, płci, statusu naukowego i zainteresowań badawczych osób, których konta zostały rozpoznane $\mathrm{w}$ badanych serwisach. Następnie przy użyciu metod ilościowych ukazano strukturę demograficzną polskich specjalistów z zakresu informatologii i bibliologii, posiadających konta w Academia.edu i ResearchGate. Wyniki i wnioski - Badania 
umożliwiły ukazanie portretu przedstawiciela informatologii i bibliologii jako użytkownika mediów społecznościowych dla naukowców ograniczonego do zakresu cech wieku, płci, statusu naukowego i zainteresowań badawczych. Obraz badacza, zarejestrowanego w serwisie Academia.edu i ResearchGate, który wyłonił się jako wynik przeprowadzonych badań, pokazuje, że w większości skończył on 35 lat, jest kobieta, ze stopniem naukowym doktora, zatrudnionym na stanowisku adiunkta, specjalizującym się w sposób porównywalny $\mathrm{w}$ informatologii lub bibliologii.

\section{WPROWADZENIE}

Wzrost popularności mediów społecznościowych w środowisku akademickim przyczynił się do istotnych zmian w komunikacji naukowej. Publikowanie w prestiżowych czasopismach z najwyższymi wskaźnikami wpływu czy wystąpienia na konferencjach naukowych wciąż dominują w przepływie informacji naukowej, jednak coraz częściej duże znaczenie zyskuje również aktywny udział badaczy w wymianie wiedzy i doświadczeń w serwisach społecznościowych dla naukowców.

Profil $\mathrm{w}$ portalu społecznościowym poświęconym nauce powoli staje się wizytówką badacza w sieci, będąc jednocześnie otwartym repozytorium, umożliwiającym promocję dorobku naukowego oraz interaktywną platformą do budowania sieci wzajemnych kontaktów z innymi naukowcami. Społeczne serwisy naukowe dostarczają również altmetrycznych narzędzi oceny publikacji naukowych w nich zdeponowanych, wspomagając tradycyjny system ewaluacji nauki oparty na bibliometrii (Rozkosz, 2014; Rodgers, Barbrow, 2014; Rychlik, 2017; Kowalska, 2017).

\section{PRZEGLĄD PIŚMIENNICTWA}

Media społecznościowe, w tym również portale zrzeszające ludzi nauki, są obszarem zainteresowań badaczy z różnych obszarów wiedzy, m.in. socjologii, psychologii, medioznawstwa czy zarządzania. Problematyka udziału naukowców $\mathrm{w}$ akademickich serwisach społecznościowych stanowi niezwykle interesujący temat, poruszany zarówno na gruncie literatury krajowej, jak i światowej.

Wśród polskich publikacji można wyróżnić artykuły o charakterze przeglądowym, omawiające zasady działania portali społecznościowych dla naukowców. Emanuel Kulczycki przeanalizował zalety wykorzystania serwisów Academia.edu i Google Scholar Citations w pracy naukowej (Kulczycki, 2012), Beata Stachowiak zaprezentowała jako portale przydatne akademikom: ResearchGate, ResearcherID, Index Copernicus Scientists i Academia.edu (Stachowiak, 2013), Ewa Rozkosz przedstawiła wybrane funkcje Academia.edu i ResearchGate (Rozkosz, 2014), a Marzena Taterczyńska, Renata Klimko i Edyta Rogowska ukazały korzyści wynikające 
z posiadania przez naukowca profilu w ResearcherID, ResearchGate i ORCID (Taterczyńska, Klimko, Rogowska, 2015).

Zagadnienie obecności i aktywności polskich badaczy reprezentujących dziedzinę informatologii i bibliologii w mediach społecznościowych, zarówno tych tradycyjnych, jak i przeznaczonych dla naukowców, nie doczekało się jeszcze wyczerpującego opracowania, chociaż można wskazać kilka ważnych badań, które potwierdzają obecność tej grupy specjalistów w akademickiej przestrzeni społecznościowej. Zaliczyć do nich można badania ankietowe Lidii Jarskiej z czerwca 2015 r. dotyczące obecności i aktywności 209 informatologów i bibliologów w ogólnodostępnych serwisach społecznościowych. Na ich podstawie można stwierdzić, że 35 ankietowanych posiada konto na Facebooku, z czego większość to osoby ze stopniem naukowym doktora, w przedziale wiekowym 31-50, 20 naukowców jest zarejestrowanych w LinkedIn, 12 badanych ma konto na Twitterze, a 11 osób jest obecnych na portalu GoldenLine (Jarska, 2016). Szczególnie interesujące są badania Bernardety Iwańskiej-Cieślik z marca 2015 r. na temat wykorzystania przez 261 przedstawicieli informatologii i bibliologii różnych kanałów przestrzeni sieciowej do prezentacji własnego dorobku naukowego, w tym również społecznych serwisów naukowych Academia.edu i ResearchGate. Zgodnie z ich wynikami 51 informatologów i bibliologów używa serwisu Academia.edu do udostępniania publikacji ( $w$ tej grupie zaobserwowano dominację kobiet oraz osób ze stopniem naukowym doktora), z kolei z ResearchGate korzysta 37 specjalistów z zakresu informatologii i bibliologii (Iwańska-Cieślik, 2016).

W międzynarodowym piśmiennictwie można odnaleźć znacznie więcej prac na temat zachowań naukowców w sieciach społecznościowych dla nich przeznaczonych. Najczęściej artykuły prezentują strukturę demograficzną konkretnych grup użytkowników akademickich mediów społecznościowych, ukazując zależność między posiadaniem konta w wybranym portalu a płcia, wiekiem, statusem naukowym oraz zainteresowaniami badawczymi. Na uwage zasługują badania Jose Luisa Ortegi dotyczące obecności członków hiszpańskiej Consejo Superior de Investigaciones Científicas w Academia.edu, ResearchGate i Google Scholar Citations $\mathrm{w}$ podziale na dyscypliny badawcze, status naukowy oraz płeć (Ortega, 2017). Interesujących wyników dostarczyły również badania prowadzone w następujących środowiskach: badaczy reprezentujących instytuty informacji naukowej i bibliotekoznawstwa irańskich uniwersytetów w ResearchGate (Asnafi, 2017), pracowników naukowych COMSATS University Islamabad w ResearchGate, Academia.edu, LinkedIn, Mendeley i Zotero (Sheikh, 2016), naukowców afiliowanych przy Pondicherry University w ResearchGate (Singson, Amees, 2017), przedstawicieli katalońskich uniwersytetów w Academia.edu (Nández, Borrego, 2013) oraz badaczy związanych z wybranymi arabskimi uniwersytetami w ResearchGate (El- 
sayed, 2016). Spora część wymienionych badań analizuje również motywacje udziału akademików w naukowym życiu społecznościowym (Van Noorden, 2014; Muscanell; Utz, 2017), ukazując też ich opinie na temat korzystania z mediów społecznościowych dla naukowców (Nández, Borrego, 2013; Elsayed, 2016; Singson, Amees, 2017).

\section{METODYKA ROZPOZNANIA OBECNOŚCI PRZEDSTAWICIELI POLSKIEJ INFORMATOLOGII I BIBLIOLOGII W SERWISACH ADACEMIA.EDU ORAZ RESEARCHGATE}

Rozpoznanie obecności przedstawicieli polskiej informatologii i bibliologii w Academia.edu i ResearchGate wymagało wcześniejszego utworzenia bazy danych zawierającej wykaz pracowników jednostek działających $\mathrm{w}$ ramach publicznych szkół wyższych prowadzących działalność badawczą z zakresu informatologii i bibliologii oraz jednostek działających w ramach publicznych szkół wyższych prowadzących kierunki studiów, w przypadku których zakładane efekty kształcenia odnoszą się do informatologii i bibliologii. Rejestr 232 polskich informatologów i bibliologów ${ }^{1}$ został oparty o strony internetowe dotyczące kadry pracowników następujących jednostek:

1. Zakład Informacji Naukowej Wydziału Pedagogiczno-Artystycznego w Kaliszu (wydział zamiejscowy Uniwersytetu Adama Mickiewicza w Poznaniu) (UAM).

2. Instytut Informacji Naukowej i Bibliotekoznawstwa Uniwersytetu Jagiellońskiego (UJ).

3. Instytut Dziennikarstwa i Informacji Uniwersytetu Jana Kochanowskiego w Kielcach (UJK).

4. Katedra Informacji Naukowej i Bibliologii Uniwersytetu Kazimierza Wielkiego w Bydgoszczy (UKW).

5. Katedra Informatologii i Bibliologii Uniwersytetu Łódzkiego (UŁ).

6. Instytut Informacji Naukowej i Bibliotekoznawstwa Uniwersytetu Marii Curie-Skłodowskiej w Lublinie (UMCS).

7. Instytut Informacji Naukowej i Bibliologii Uniwersytetu Mikołaja Kopernika w Toruniu (UMK).

8. Instytut Nauk o Informacji Uniwersytetu Pedagogicznego w Krakowie (UP).

9. Instytut Bibliotekoznawstwa i Informacji Naukowej Uniwersytetu Śląskiego (UŚ).

\footnotetext{
${ }^{1}$ Rozbieżności między ogólną liczbą informatologów i bibliologów w proponowanych badaniach a ogólną liczbą informatologów i bibliologów prezentowaną w badaniach Lidii Jarskiej i Bernardety Iwańskiej-Cieślik wynikają m.in. ze zmian personalnych zachodzących w zespołach pracowników badanych instytutów, katedr i zakładów bibliologicznych i informatologicznych.
} 
10. Zakład Archiwistyki, Bibliotekoznawstwa i Informacji Naukowej Uniwersytetu Warmińsko-Mazurskiego w Olsztynie (UWM).

11. Wydział Dziennikarstwa, Informacji i Bibliologii Uniwersytetu Warszawskiego (UW).

12. Instytut Informacji Naukowej i Bibliotekoznawstwa Uniwersytetu Wrocławskiego (UWr).

W badaniach nie uwzględniono pracowników jednostek naukowo-dydaktycznych prowadzących jedynie studia podyplomowe $\mathrm{z}$ zakresu informatologii i bibliologii (m.in. Uniwersytet Zielonogórski, Uniwersytet Rzeszowski czy Uniwersytet Opolski), a także pracowników jednostek naukowo-dydaktycznych nieposiadających samodzielnych instytutów, katedr czy zakładów (m.in. zespół Informacji Naukowej i Humanistyki Cyfrowej funkcjonujący w obrębie Zakładu Filologicznych Badań Interdyscyplinarnych Uniwersytetu w Białymstoku). W badaniach nie uwzględniono również osób prowadzących działalność dydaktyczno-badawczą zatrudnionych $\mathrm{w}$ bibliotekach akademickich. Zarówno zmiany personalne zachodzące w kadrze poszczególnych jednostek, jak i pojawiające się $\mathrm{w}$ badanych serwisach nowe konta przedstawicieli polskiej informatologii i bibliologii nie były brane pod uwagę po okresie zbudowania bazy danych datowanym na grudzień 2017.

Głównym celem badania jest rozpoznanie aspektów obecności przedstawicieli polskiej informatologii i bibliologii w serwisach Academia.edu i ResearchGate ograniczonych do zakresu cech płci, wieku, statusu naukowego i zainteresowań badawczych. Wybór portali został uzasadniony ich popularnością w środowisku naukowym, o czym świadczą statystyki dotyczące zarejestrowanych użytkowników - Academia.edu deklaruje 72080735 kont, a ResearchGate około 15 mln kont [stan na 18.01.2019].

Przedmiotem badania jest obecność polskich informatologów i bibliologów w Academia.edu i ResearchGate, rozumiana jako „bycie” na tych portalach, czyli dobrowolne założenie konta w Academia.edu i ResearchGate, identyfikowanego imieniem i nazwiskiem, niezależnie od formy i stopnia zaangażowania $\mathrm{w}$ działania prowadzone w jego obrębie. Warto uściślić także, że słowo „obecność" nie jest tutaj traktowane jako wyrażenie synonimiczne do słowa "aktywność", przez co osoby niewykazujące się jakąkolwiek aktywnością $\mathrm{w}$ analizowanych serwisach, czyli posiadające tzw. martwe konta, były kwalifikowane do badań, w przeciwieństwie do kont tworzonych automatycznie przez Academia.edu i ResearchGate, które pominięto, gdyż są one generowane w oparciu o algorytmy wyszukiwania danych gromadzonych w ogólnodostępnych bazach danych, $\mathrm{w}$ tym przede wszystkim w publikacjach pełnotekstowych zawierających afiliacje autorów (Van Noorden, 2014). 
Sformułowano dwie tezy badawcze:

1. Przedstawiciele polskiej informatologii i bibliologii są obecni w portalach Academia.edu i ResearchGate.

2. W strukturze polskich informatologów i bibliologów obecnych w serwisach Academia.edu i ResearchGate przeważają kobiety wykazujące się statusem młodego pracownika nauki, posiadające tytuł zawodowy magistra lub stopień naukowy doktora, zatrudnione na stanowisku asystenta, specjalizujące się w informatologii.

Badania zostały przeprowadzone w lutym 2018 r. Gromadzenie danych o pracownikach zostało ograniczone do następujących zmiennych:

- wiek (w dychotomicznym podziale na młodszego i starszego pracownika naukowego),

- płeć,

- status naukowy (wykształcenie oraz stanowisko),

- zainteresowania badawcze.

Do opracowania danych wykorzystano metodę ilościowa, statystyczną. Osoby posiadające konta w serwisach Academia.edu oraz ResearchGate w pierwszej kolejności zostały wyszukane za pomocą imienia i nazwiska oraz afiliacji. W przypadku gdy te informacje nie wystarczały do jednoznacznego rozpoznania konta danego naukowca, przeanalizowano, czy w zasubskrybowanych przez niego dyscyplinach badawczych jest informatologia lub bibliologia lub dziedziny pokrewne tym dwóm dyscyplinom (prasoznawstwo, literaturoznawstwo, prawo, historia, socjologia i filozofia). Jeśli w dalszym ciągu były wątpliwości co do jednoznacznego rozpoznania konta badacza, zostały prześledzone jego sieci networkingowe pod kątem występowania w kręgach followers i following użytkowników zajmujących się informatologią i bibliologią. Przy potwierdzaniu, czy odnalezione konto jest właśnie kontem szukanego badacza, były przydatne powiązane konta serwisów Facebook, Google+ i LinkedIn, z kolei identyfikatory ORCID i ResearcherID okazały się bezużyteczne, gdyż w bardzo ograniczonej liczbie przypadków były połączone z kontami poszukiwanych osób w Academia.edu i ResearchGate.

Zgodnie z założoną metodyką spośród grupy 232 pracowników naukowych związanych z informatologią i bibliologią zostało rozpoznanych 102 badaczy obecnych w serwisach Academia.edu i ResearchGate.

Metodyka ustalenia obecności przedstawicieli informatologii i bibliologii w serwisach Academia.edu i ResearchGate może zostać wykorzystana do rozpoznania kont specjalistów jakiejkolwiek dziedziny wiedzy w różnego typu mediach społecznościowych. 


\section{OBECNOŚĆ PRZEDSTAWICIELI POLSKIEJ INFORMATOLOGII}

\section{BIBLIOLOGII W SERWISACH ACADEMIA.EDU ORAZ RESEARCHGATE}

W wyniku wielostopniowych przeszukiwań wśród 232 przedstawicieli polskiej informatologii i bibliologii zostało rozpoznanych 102 badaczy (44\%) posiadających konta w jednym $\mathrm{z}$ analizowanych serwisów lub w obu równocześnie, co oznacza, że 130 badaczy (56\%) z zakresu informatologii i bibliologii nie ma konta ani w Academia.edu, ani w ResearchGate.

W serwisie Academia.edu zostały wyszukane 84 konta, a w portalu ResearchGate 66 kont, co daje sumę 150 wszystkich kont przedstawicieli informatologii i bibliologii. Warto zwrócić uwagę na rozbieżność między liczbą badaczy a liczbą kont wynikającą z obecności 48 osób w obu serwisach jednocześnie. Podstawą do analiz statystycznych była liczba 102 badaczy posiadających konta $\mathrm{w}$ jednym $\mathrm{z}$ analizowanych serwisów lub w obu równocześnie. Dane te zostały ukazane w tabeli 1.

Tabela 1

Liczba kont przedstawicieli polskiej informatologii i bibliologii w serwisach Academia.edu lub ResearchGate.

\begin{tabular}{|l|c|c|c|c|c|c|c|}
\cline { 2 - 8 } \multicolumn{1}{c|}{} & $\begin{array}{c}\text { Ogólna } \\
\text { liczba } \\
\text { pracowników }\end{array}$ & $\begin{array}{c}\text { Liczba } \\
\text { osób } \\
\text { z kontami } \\
\text { w Academia. } \\
\text { edu }\end{array}$ & $\begin{array}{c}\text { Liczba } \\
\text { osób } \\
\text { z kontami } \\
\text { w Research } \\
\text { Gate }\end{array}$ & $\begin{array}{c}\text { Liczba } \\
\text { osób } \\
\text { z kontami } \\
\text { tylko } \\
\text { w Academia. } \\
\text { edu }\end{array}$ & $\begin{array}{c}\text { Liczba } \\
\text { osób } \\
\text { z kontami } \\
\text { tylko } \\
\text { wesearch } \\
\text { Gate }\end{array}$ & $\begin{array}{c}\text { Liczba } \\
\text { osób } \\
\text { z kontami } \\
\text { w obu } \\
\text { serwisach }\end{array}$ & $\begin{array}{c}\text { Liczba } \\
\text { osób } \\
\text { bez } \\
\text { kont }\end{array}$ \\
\hline UAM & 9 & 3 & 2 & 2 & 1 & 1 & 5 \\
\hline UJ & 20 & 6 & 11 & 0 & 5 & 6 & 9 \\
\hline UJK & 21 & 6 & 1 & 6 & 1 & 0 & 14 \\
\hline UKW & 8 & 3 & 2 & 2 & 1 & 1 & 4 \\
\hline UŁ & 13 & 6 & 4 & 4 & 2 & 2 & 5 \\
\hline UMCS & 15 & 8 & 4 & 4 & 0 & 4 & 7 \\
\hline UMK & 17 & 10 & 8 & 3 & 1 & 7 & 6 \\
\hline UP & 19 & 6 & 4 & 3 & 1 & 3 & 12 \\
\hline UŚ & 34 & 9 & 5 & 4 & 0 & 5 & 25 \\
\hline UWM & 5 & 2 & 3 & 0 & 1 & 2 & 2 \\
\hline UW & 42 & 18 & 14 & 5 & 1 & 13 & 23 \\
\hline UWr & 29 & 7 & 8 & 3 & 4 & 4 & 18 \\
\hline & 232 & 84 & 66 & 36 & 18 & 48 & 130 \\
\hline
\end{tabular}

Źródło: oprac. własne.

Występowanie kont $\mathrm{w}$ serwisie Academia.edu jest zauważalnie większe. Wynika to z dużej popularności portalu w Polsce i na świecie, a także 
z mniej skomplikowanej procedury zakładania konta, a następnie obsługi samego profilu. Dysproporcję pomiędzy liczbą użytkowników można uzasadnić także warunkami rejestracji: Academia.edu umożliwia zakładanie konta bez jakichkolwiek ograniczeń, z użyciem prywatnego adresu poczty elektronicznej, a ResearchGate wymaga przy rejestracji podania adresu poczty elektronicznej $w$ domenie jednostki naukowej, $z$ którą związany jest dany badacz i nie ma tutaj możliwości logowania przez konto Facebooka lub Google+, co także znacznie ogranicza krąg nieaktywnych użytkowników i martwych kont w tym serwisie. Przewaga naukowców posiadających konta w Academia.edu wśród informatologów i bibliologów również została zaobserwowana w badaniach B. Iwańskiej-Cieślik dotyczących stosowania przez przedstawicieli informatologii i bibliologii różnych kanałów przestrzeni sieciowej do promocji własnego dorobku naukowego (Iwańska-Cieślik, 2016).

\section{OBECNOŚĆ PRZEDSTAWICIELI POLSKIEJ INFORMATOLOGII I BIBLIOLOGII W SERWISACH ACADEMIA.EDU ORAZ RESEARCHGATE WEDEUG WIEKU}

Wśród przedstawicieli polskiej informatologii i bibliologii zostały wyszczególnione dwie kategorie wiekowe: młodzi pracownicy naukowi, których wiek nie przekroczył 35 lat oraz pozostali pracownicy naukowi, którzy ukończyli 35. rok życia. To rozróżnienie zostało przyjęte na podstawie obowiązującej do 30 września 2018 r. Ustawy z dnia 30 kwietnia 2010 r. o zasadach finansowania nauki, która jako młodego badacza określała „osobę prowadzącą działalność badawczo-rozwojowa która w roku ubiegania się o przyznanie środków finansowych na naukę kończy nie więcej niż 35 lat". Wiek badaczy został oszacowany na podstawie informacji o datach uzyskania przez nich stopni i tytułów zgromadzonych w bazie Nauka Polska Ośrodka Przetwarzania Informacji - Państwowego Instytutu Badawczego. Jeśli dane dostępne w bazie Nauka Polska były niewystarczające do określenia, czy dany naukowiec jest młodym pracownikiem naukowym czy pracownikiem, który ukończył 35. rok życia, zostały wyszukane informacje o jego wieku w ogólnodostępnych bazach danych, katalogach bibliotecznych, czasem również w innych mediach społecznościowych. Wszelkie modyfikacje wyników badań mogą być spowodowane jedynie szacowaniem danych dotyczących wieku.

W strukturze wiekowej przedstawicieli polskiej informatologii i bibliologii obecnych w którymkolwiek z serwisów Academia.edu lub ResearchGate dominują pracownicy naukowi po 35. roku życia, których jest 88 $(86 \%)$, natomiast przedstawicieli informatologii i bibliologii ze statusem młodego naukowca jest 14 (14\%). 
W gronie młodych specjalistów z zakresu informatologii i bibliologii przeważają konta tylko w Academia.edu, których jest sześć (43\%), konta jedynie w ResearchGate posiadają cztery osoby (28,5\%), z kolei obecnych $\mathrm{w}$ jednym i w drugim serwisie zostało odnotowanych czterech naukowców (28,5\%). Wśród przedstawicieli informatologii i bibliologii po 35. roku życia 27 osób (31\%) jest zarejestrowanych tylko w Academia.edu, 17 osób tylko w ResearchGate (19\%), a z obu serwisów równocześnie korzysta 44 pracowników (50\%). Rozkład tych danych zawiera tabela 2.

Tabela 2

Liczba kont przedstawicieli polskiej informatologii i bibliologii w serwisach Academia.edu lub ResearchGate według wieku.

\begin{tabular}{|l|c|c|c|c|}
\cline { 2 - 5 } & $\begin{array}{c}\text { Liczba pracowników } \\
\text { obecnych } \\
\text { w Academia.edu } \\
\text { lub ResearchGate }\end{array}$ & $\begin{array}{c}\text { Liczba osób } \\
\text { z kontami tylko } \\
\text { w Academia.edu }\end{array}$ & $\begin{array}{c}\text { Liczba osób } \\
\text { z kontami tylko } \\
\text { w ResearchGate }\end{array}$ & $\begin{array}{c}\text { Liczba osób } \\
\text { z kontami } \\
\text { w obu } \\
\text { serwisach }\end{array}$ \\
\hline $\begin{array}{l}\text { Liczba młodych } \\
\text { pracowników }\end{array}$ & 14 & 6 & 4 & 4 \\
\hline $\begin{array}{l}\text { Liczba } \\
\text { pozostałych } \\
\text { pracowników }\end{array}$ & 88 & 27 & 17 & 44 \\
\hline & 102 & 33 & 21 & 48 \\
\hline
\end{tabular}

Źródło: oprac. własne.

Większa liczba specjalistów z zakresu informatologii i bibliologii po 35. roku życia w analizowanych serwisach społecznościowych dla naukowców jest uwarunkowana ogólną dominacją tej kategorii wiekowej w badanych jednostkach. Na podstawie raportu Głównego Urzędu Statystycznego Nauka i technika 2016 zaobserwowano również, że większość osób wykonujących prace naukowo-badawcze, zatrudnionych w publicznych szkołach wyższych, przekroczyła 35. rok życia, co dodatkowo uzasadnia większy udział osób po 35. roku życia w strukturze wiekowej przedstawicieli informatologii i bibliologii obecnych w badanych serwisach. Założenie przyjętej tezy o większym udziale młodych pracowników naukowych w społecznych serwisach naukowych nie potwierdziło się. Jak wynika z badań, informatolodzy i bibliolodzy z racji wykonywanej profesji bez względu na wiek są bardzo dobrze zaznajomieni z najnowszą technologią w zakresie udostępniania informacji, także za pośrednictwem mediów społecznościowych, traktując je jako kolejne wartościowe bazy danych pozwalające na otwarty obieg informacji, a liczna reprezentacja osób po 35 . roku życia przełamuje pewien stereotyp wycofania i izolacji pokolenia badaczy, którzy nie dorastali w świecie zaawansowanych technologii, przez co dopiero w dorosłym życiu musieli się przestawić na cyfrową naukę. 


\section{OBECNOŚĆ PRZEDSTAWICIELI POLSKIEJ INFORMATOLOGII I BIBLIOLOGII W SERWISACH ACADEMIA.EDU ORAZ RESEARCHGATE WEDŁUG PŁCI}

Zróżnicowanie obecności przedstawicieli informatologii i bibliologii w serwisach Academia.edu i ResearchGate względem płci ukazuje przewagę kobiet, których jest 61 (60\%), natomiast liczba mężczyzn wynosi 41 $(40 \%)$.

Wśród badaczy z zakresu informatologii i bibliologii płci żeńskiej aktywnych w portalach Academia.edu lub ResearchGate można wyróżnić 20 kobiet (33\%) posiadających konta tylko w Academia.edu, 10 (16\%) mających konta wyłącznie w ResearchGate oraz 31 (51\%) zarejestrowanych równocześnie w obu serwisach. Jeśli chodzi o płeć męską 16 mężczyzn (39\%) ma konta jedynie w Academia.edu, osiem (20\%) tylko w ResearchGate, a 17 (41\%) jednocześnie w obu serwisach. Dane na temat płci zostały ukazane w tabeli 3.

Tabela 3

Liczba kont przedstawicieli polskiej informatologii i bibliologii w serwisach Academia.edu lub ResearchGate według płci.

\begin{tabular}{|l|c|c|c|c|}
\cline { 2 - 5 } \multicolumn{1}{c|}{} & $\begin{array}{c}\text { Liczba pracowników } \\
\text { obecnych } \\
\text { w Academia.edu } \\
\text { lub ResearchGate }\end{array}$ & $\begin{array}{c}\text { Liczba osób } \\
\text { z kontami tylko } \\
\text { w Academia.edu }\end{array}$ & $\begin{array}{c}\text { Liczba osób z } \\
\text { kontami tylko w } \\
\text { ResearchGate }\end{array}$ & $\begin{array}{c}\text { Liczba osób } \\
\text { z kontami } \\
\text { w obu serwisach }\end{array}$ \\
\hline Kobiety & 61 & 20 & 10 & 31 \\
\hline Mężczyźni & 41 & 16 & 8 & 17 \\
\hline & 102 & 36 & 18 & 48 \\
\hline
\end{tabular}

Źródło: oprac. własne.

Wśród specjalistów polskiej informatologii i bibliologii ogólnie dominują kobiety ${ }^{2}$. B. Iwańska-Cieślik podczas badań wykorzystania przez przedstawicieli informatologii i bibliologii różnych kanałów przestrzeni sieciowej do prezentacji własnego dorobku naukowego również ustaliła przewagę kobiet nad mężczyznami, w tym rozpoznała 31 kobiet i 20 mężczyzn korzystających z Academia.edu do rozpowszechniania własnych publikacji (Iwańska-Cieślik, 2016).

Założenie tezy odnoszące się do płci zostało potwierdzone - wśród specjalistów z zakresu informatologii i bibliologii obecnych w serwisach

\footnotetext{
${ }^{2}$ Według badań własnych wśród kadry badanych jednostek można wyróżnić $66 \%$ naukowców płci żeńskiej i 34\% badaczy płci męskiej [stan na luty 2018].
} 
społecznościowych Academia.edu i ResearchGate przeważają kobiety. Dysproporcja ta nie jest jednak aż tak znacząca, co może sugerować zachodzące powolne zmiany i coraz większą widoczność mężczyzn, zwłaszcza w kontekście ich aktywności w rozwoju technologii informatycznych i nowoczesnych mediów we współczesnej informatologii i bibliologii.

\section{OBECNOŚĆ PRZEDSTAWICIELI POLSKIEJ INFORMATOLOGII I BIBLIOLOGII W SERWISACH ACADEMIA.EDU ORAZ RESEARCHGATE WED€UG STATUSU NAUKOWEGO}

Zgodnie z obowiązującymi w Polsce etapami kariery naukowej wśród przedstawicieli informatologii i bibliologii zostały wyodrębnione osoby posiadające: tytuł zawodowy magistra, stopień naukowy doktora i doktora habilitowanego oraz tytuł naukowy profesora. Stosownie do struktury organizacyjnej poszczególnych uczelni zostały wyróżnione stanowiska wykładowcy, starszego wykładowcy, asystenta, adiunkta oraz profesora. Przyjęte kryteria statusu naukowego zostały określone na podstawie stron internetowych poszczególnych jednostek uczelni oraz bazy danych Nauka Polska Ośrodka Przetwarzania Informacji - Państwowego Instytutu Badawczego.

Największa liczba kont została zaobserwowana w przypadku pracowników ze stopniem naukowym doktora, których jest 64 (62,74\%). Drugą dużą grupą są osoby ze stopniem naukowym doktora habilitowanego, liczącą 21 osób (20,58\%). Badaczy z tytułem naukowym profesora jest 11 $(10,78 \%)$. Najmniejszą grupe reprezentowały osoby z tytułem zawodowym magistra, w liczbie zaledwie $6(5,88 \%)$.

Wśród badaczy zarejestrowanych tylko w Academia.edu jest 26 osób (72\%) ze stopniem naukowym doktora, cztery osoby (11\%) ze stopniem naukowym doktora habilitowanego, cztery osoby (11\%) z tytułem naukowym profesora, dwie osoby $(6 \%)$ z tytułem zawodowym magistra. W gronie naukowców obecnych tylko w ResearchGate jest 13 osób (72\%) ze stopniem naukowym doktora, dwie $(11 \%)$ z tytułem naukowym profesora, dwie $(11 \%)$ ze stopniem naukowym doktora habilitowanego i jedna $(6 \%)$ z tytułem zawodowym magistra. W zespole pracowników posiadających konta jednocześnie w obu serwisach jest 25 osób (52,08\%) ze stopniem naukowym doktora, 15 osób $(31,25 \%)$ ze stopniem naukowym doktora habilitowanego, pięć osób (10,41\%) z tytułem naukowym profesora oraz trzy osoby $(6,25 \%)$ z tytułem zawodowym magistra. Dane te zostały przedstawione $\mathrm{w}$ tabeli 4 . 
Liczba kont przedstawicieli polskiej informatologii i bibliologii w serwisach Academia.edu lub ResearchGate według statusu naukowego.

\begin{tabular}{|l|c|c|c|c|}
\cline { 2 - 5 } \multicolumn{1}{c|}{} & $\begin{array}{c}\text { Liczba pracowników } \\
\text { obecnych } \\
\text { w Academia.edu } \\
\text { lub ResearchGate }\end{array}$ & $\begin{array}{c}\text { Liczba osób } \\
\text { z kontami tylko } \\
\text { w Academia.edu }\end{array}$ & $\begin{array}{c}\text { Liczba osób } \\
\text { z kontami tylko } \\
\text { w ResearchGate }\end{array}$ & $\begin{array}{c}\text { Liczba osób } \\
\text { z kontami } \\
\text { w obu serwisach }\end{array}$ \\
\hline Mgr & 6 & 2 & 1 & 3 \\
\hline Dr & 64 & 26 & 13 & 25 \\
\hline Dr hab. & 21 & 4 & 2 & 15 \\
\hline Profesor & 11 & 4 & 2 & 5 \\
\hline & 102 & 36 & 18 & 48 \\
\hline
\end{tabular}

Źródło: oprac. własne.

Z punktu widzenia struktury organizacyjnej najliczniejszym zespołem obecnym $\mathrm{w}$ którymkolwiek lub w obu badanych serwisach społecznościowych są osoby zatrudnione na stanowisku adiunkta, których jest 67 $(65,68 \%)$. Kolejna, co do wielkości grupę użytkowników serwisów, stanowią badacze na stanowisku profesora, których odnotowano 18 (17,64\%). Na następnym miejscu plasują się asystenci: 9 osób (9\%), dalej starsi wykładowcy: 6 osób (6\%) i na końcu wykładowcy: 2 osoby (2\%).

Wśród specjalistów informatologii i bibliologii obecnych w Academia. edu lub ResearchGate proporcje dotyczące stanowiska kształtują się następująco: w kręgu naukowców mających konta wyłącznie w Academia. edu jest 20 adiunktów (56\%), 7 profesorów (19\%), 5 asystentów (14\%), 3 starszych wykładowców (8\%) i 1 wykładowca (3\%), we wspólnocie badaczy z kontem tylko w ResearchGate zostało zanotowanych 11 adiunktów (61,11\%), 3 profesorów (16,67\%), 2 asystentów (11,11\%) i 2 starszych wykładowców $(11,11 \%)$, a wewnątrz grupy pracowników posiadających konta równolegle $\mathrm{w}$ obu serwisach zostało zewidencjonowanych 36 adiunktów (75\%), 8 profesorów (16,67\%), 2 asystentów (4,16\%), 1 starszy wykładowca (2,08\%) i 1 wykładowca (2,08\%). Dane te zostały udostępnione w tabeli 5 . 
Liczba kont przedstawicieli polskiej informatologii i bibliologii w serwisach Academia.edu lub ResearchGate według statusu naukowego.

\begin{tabular}{|l|c|c|c|c|}
\cline { 2 - 5 } \multicolumn{1}{c|}{} & $\begin{array}{c}\text { Liczba pracowników } \\
\text { obecnych } \\
\text { w Academia.edu } \\
\text { lub ResearchGate }\end{array}$ & $\begin{array}{c}\text { Liczba osób } \\
\text { z kontami tylko } \\
\text { w Academia.edu }\end{array}$ & $\begin{array}{c}\text { Liczba osób } \\
\text { z kontami tylko } \\
\text { w ResearchGate }\end{array}$ & $\begin{array}{c}\text { Liczba osób } \\
\text { z kontami } \\
\text { w obu } \\
\text { serwisach }\end{array}$ \\
\hline Wykładowca & 2 & 1 & 0 & 1 \\
\hline $\begin{array}{l}\text { Starszy } \\
\text { wykładowca }\end{array}$ & 6 & 3 & 2 & 1 \\
\hline Asystent & 9 & 5 & 2 & 2 \\
\hline Adiunkt & 67 & 20 & 11 & 36 \\
\hline Profesor & 18 & 7 & 3 & 8 \\
\hline & 102 & 36 & 18 & 48 \\
\hline
\end{tabular}

Źródło: oprac. własne.

Zestawiając dane dotyczące statusu naukowego, 53 osoby $(51,96 \%)$ posiadające konta w Academia.edu lub ResearchGate legitymują się stopniem naukowym doktora i są zatrudnione na stanowisku adiunkta. Adiunktów ze stopniem naukowym doktora habilitowanego zostało odnotowanych 14 (13,72\%). Wśród badaczy na stanowisku profesora 7 osób (6,86\%) posiadało stopień naukowy doktora habilitowanego, natomiast 11 $(10,78 \%)$ tytuł naukowy profesora. Wśród asystentów 5 badaczy $(4,9 \%)$ wykazuje się stopniem naukowym doktora, reszta asystentów posiada tytuł zawodowy magistra -4 osoby (3,92\%). Starsi wykładowcy to osoby wyłącznie ze stopniem naukowym doktora, których jest $6(5,88 \%)$, z kolei wykładowcy to magistrzy, w liczbie 2 osób (1,96\%).

Dane dotyczące statusu naukowego badaczy z zakresu informatologii i bibliologii posiadających konta $\mathrm{w}$ analizowanych serwisach społecznościowych odwzorowują ogólną dominację osób posiadających stopień naukowy doktora zatrudnionych na stanowisku adiunkta $\mathrm{w}$ badanych uniwersytetach. Powołując się na zestawienie Głównego Urzędu Statystycznego Nauka i technika w 2016, zaobserwowane zależności są też zgodne $\mathrm{z}$ generalnymi trendami prymatu osób ze stopniem naukowym doktora, zatrudnionych w publicznych szkołach wyższych, których jest $44 \%$ w Polsce. Podobna przewaga naukowców ze stopniem naukowym doktora została także zaobserwowana w badaniach B. Iwańskiej-Cieślik dotyczących możliwości przestrzeni sieciowej do prezentacji własnego dorobku naukowego wykorzystywanych przez specjalistów z zakresu informatologii i bibliologii, zarówno w ogólnej charakterystyce analizowanej grupy (wśród zbadanych 261 informatologów i bibliologów 123 osoby były doktorami), jak również wśród badaczy ze stopniem na- 
ukowym doktora korzystających z Academia.edu, których odnotowano 26 (Iwańska-Cieślik, 2016). Założenie tezy odnośnie dominacji informatologów i bibliologów w Academia.edu i ResearchGate posiadających tytuł zawodowy magistra lub stopień naukowy doktora, zatrudnionych na stanowisku asystenta potwierdziły się częściowo. Osób ze stopniem naukowym doktora jest rzeczywiście najwięcej w badanej grupie, jednak są oni częściej zatrudnieni głównie na stanowisku adiunkta, z kolei badacze z tytułem zawodowym magistra stanowią mniejszość.

Akademicy ze stopniem naukowym doktora są zdecydowanie najbardziej aktywną grupą ze względu na to, że gromadzą dorobek naukowy w celu uzyskania habilitacji, która stanowi moment kluczowy ich kariery naukowej, umożliwiający prowadzenie własnych badań i kierowanie projektami badawczymi. Ponadto obligatoryjny do momentu wejścia w życie nowej ustawy z dnia 20 lipca 2018 r. Prawo o szkolnictwie wyższym i nauce formalny wymóg habilitacji do ośmiu lat od uzyskania stopnia naukowego doktora stanowił dodatkowy czynnik mobilizujący, aczkolwiek mimo obecnego zniesienia obowiązku habilitacji, doktorzy wciąż muszą pomnażać swój dorobek naukowy w celu rozwoju dyscypliny, w której się specjalizują. Względy te stymulują doktorów do bardziej intensywnej pracy i jednym z jej przejawów może być zwiększenie aktywności w mediach społecznościowych dla naukowców, w celu dotarcia do większej liczby odbiorców treści przez nich publikowanych i podniesienia wskaźników cytowania.

\section{OBECNOŚĆ PRZEDSTAWICIELI POLSKIEJ INFORMATOLOGII I BIBLIOLOGII W SERWISACH ACADEMIA.EDU ORAZ RESEARCHGATE WEDŁUG ZAINTERESOWAŃ BADAWCZYCH}

Na podstawie danych gromadzonych przez bazę Nauka Polska Ośrodka Przetwarzania Informacji - Państwowego Instytutu Badawczego oraz Zintegrowany System Informacji o Nauce i Szkolnictwie Wyższym POL-on, a także biogramów przedstawicieli informatologii i bibliologii zamieszczonych na stronach internetowych badanych jednostek uniwersytetów zostały wyszczególnione wśród specjalizacji badawczych następujące obszary badawcze: informatologia, bibliologia oraz pozostałe dyscypliny (prasoznawstwo, literaturoznawstwo, prawo, historia, socjologia i filozofia). Jakakolwiek niedoskonałość badań na tym etapie może wynikać z trudności w przyporządkowaniu do konkretnego obszaru badawczego osób, których zainteresowania naukowe mają charakter interdyscyplinarny.

Najczęściej pojawiającymi się dyscyplinami w obrębie badanej grupy naukowców obecnych w Academia.edu lub ResearchGate są porównywalnie informatologia i bibliologia, 42 osoby specjalizują się w zakresie 
informatologii (41,17\%), a bibliologów jest 40 (39,21\%). Z kolei badaczy reprezentujących pozostałe dyscypliny zostało zanotowanych $20(19,6 \%)$.

Wśród badaczy z zakresu informatologii i bibliologii osób zajmujących się informatologią występujących jedynie w Academia.edu jest $6(14,28 \%)$, badaczy z kontami tylko w ResearchGate 7 (16,67\%), natomiast naukowców korzystających z obu serwisów 29 (69,04\%). Pośród bibliologów 19 osób $(47,5 \%)$ posiada konta tylko w Academia.edu, 9 badaczy (22,5\%) jest zarejestrowanych w ResearchGate, a 12 naukowców (30\%) ma konta $\mathrm{w}$ jednym i w drugim portalu. W zbiorowości badaczy reprezentujących pozostałe dyscypliny 11 osób (55\%) posiada konta wyłącznie w Academia.edu, $2(10 \%)$ tylko w ResearchGate, a 7 badaczy (35\%) jest obecnych w obu serwisach. Przytoczone dane zostały zobrazowane w tabeli 6.

Tabela 6

Liczba kont przedstawicieli polskiej informatologii i bibliologii w serwisach Academia.edu lub ResearchGate według specjalizacji badań.

\begin{tabular}{|l|c|c|c|c|}
\cline { 2 - 5 } \multicolumn{1}{c|}{} & $\begin{array}{c}\text { Liczba } \\
\text { pracowników } \\
\text { obecnych } \\
\text { w Academia.edu } \\
\text { lub ResearchGate }\end{array}$ & $\begin{array}{c}\text { Liczba osób } \\
\text { z kontami tylko } \\
\text { w Academia.edu }\end{array}$ & $\begin{array}{c}\text { Liczba osób } \\
\text { z kontami tylko } \\
\text { w ResearchGate }\end{array}$ & $\begin{array}{c}\text { Liczba osób } \\
\text { z kontami } \\
\text { w obu } \\
\text { serwisach }\end{array}$ \\
\hline Informatologia & 42 & 6 & 7 & 29 \\
\hline Bibliologia & 40 & 19 & 9 & 12 \\
\hline $\begin{array}{l}\text { Pozostałe } \\
\text { dyscypliny }\end{array}$ & 20 & 11 & 2 & 7 \\
\hline & 102 & 36 & 18 & 48 \\
\hline
\end{tabular}

Źródło: oprac. własne.

Założenia tezy dotyczące zainteresowań badawczych potwierdziły się częściowo, gdyż liczba badaczy specjalizujących się w informatologii i liczba osób specjalizujących się w bibliologii w badanych serwisach jest podobna. Zbliżona liczba osób obecnych w Academia.edu i ResearchGate, które prowadzą badania $\mathrm{w}$ zakresie informatologii lub w zakresie bibliologii wskazuje, że obie grupy naukowców odnajdują się w świecie nowoczesnych narzędzi wymiany informacji, wiedzy i doświadczeń, jakimi są m.in. media społecznościowe gromadzące ludzi nauki. Osoby reprezentujące zarówno informatologię jak i bibliologię wzajemnie na siebie oddziałują obcując w jednej jednostce naukowej, gdzie nie tylko ze sobą współpracuja, ale w związku z parametryzacją również konkurują. W obliczu ewaluacji efektywności pracy naukowej reprezentanci obu specjalizacji naukowych na równi doceniają potencjał promocji i popularyzacji własnych badań w przestrzeni mediów społecznościowych dla naukowców 
w celu dotarcia do jak najszerszego grona odbiorców własnych publikacji i powiększenia metryk wpływu.

\section{ZAKOŃCZENIE}

Zaprezentowane $\mathrm{w}$ artykule wyniki analiz potwierdziły obecność przedstawicieli polskiej informatologii i bibliologii w serwisach społecznościowych Academia.edu i ResearchGate, zakładaną w pierwszej tezie pracy. Założenia drugiej tezy potwierdziły się tylko częściowo, gdyż zgodnie z wynikami badań w strukturze polskich informatologów i bibliologów obecnych w serwisach Academia.edu i ResearchGate przeważają kobiety, które skończyły 35 lat, posiadają stopień naukowy doktora, są zatrudnione na stanowisku adiunkta i specjalizują się porównywalnie $\mathrm{w}$ informatologii lub bibliologii.

Niezmiernie interesującą problematyką zasługującą na osobne opracowanie jest kwestia intensywności aktywności przedstawicieli polskiej informatologii i bibliologii według cech płci, wieku, statusu naukowego i zainteresowań badawczych w serwisach Academia.edu oraz ResearchGate w dłuższej perspektywie czasowej, co stanowiłoby kontynuację i dopełnienie tego artykułu naukowego. Takie badania umożliwiłyby ukazanie typologii zachowań informatologów i bibliologów jako użytkowników portali Academia.edu i ResearchGate oraz poznanie ich motywacji do zakładania kont w mediach społecznościowych dla naukowców.

\section{BIBLIOGRAFIA}

Academia.edu (2018). Help Center [online]. Academia.edu; [dostęp: 10.06.2018]. Dostępny w WWW: <http://support.academia.edu/>.

Asnafi, Amir Reza (2017). Presence of the Iranian Library and the Information Science Departments in ResearchGate. DESIDOC Journal of Library \& Information Technology [online], vol. 37, no. 4 [dostęp: 14.10.2017]. Dostępny w WWW: <https://www.researchgate.net/publication/314263483_Presence_of_the_Iranian_Library_and_the_Information_Science_Departments_in_Research_Gate>.

Cieślik-Iwańska, Bernardeta (2015). Informacja o nowych publikacjach polskich bibliologów i informatologów w przestrzeni sieciowej (część 1). Toruńskie Studia Bibliologiczne [online], nr 1 (16) [dostęp: 12.01.2019]. Dostępny w WWW: <http://apcz.umk.pl/czasopisma/index.php/TSB/article/view/TSB.2016.011>.

Cieślik-Iwańska, Bernardeta (2015). Informacja o nowych publikacjach polskich bibliologów i informatologów w przestrzeni sieciowej (część 2). Toruńskie Studia Bibliologiczne [online], nr 2 (17) [dostęp: 12.01.2019]. Dostępny w WWW: <http://apcz.umk.pl/czasopisma/index.php/TSB/article/view/TSB.2016.026>.

Elsayed, Amany M. (2016). The Use of Academic Social Networks Among Arab Researchers: A Survey. Social Science Computer Review [online], vol. 34(3) [dostęp: 22.12.2018]. Dostępny w WWW: <https://journals.sagepub.com/doi/abs/10.1177/0894439315589146>. 
GUS (2018). Nauka i technika 2016 [online]. Główny Urząd Statystyczny; [dostęp: 27.10. 2018]. Dostępny w WWW: <http://stat.gov.pl/obszary-tematyczne/nauka-i-technikaspoleczenstwo-informacyjne/nauka-i-technika/nauka-i-technika-w-2016-roku,1,13. html>.

Jarska, Lidia (2016). Pracownik naukowy w mediach społecznościowych - od popularyzacji nauki do kreowania wizerunku. Toruńskie Studia Bibliologiczne [online], vol. 9, no. 2(17) [dostęp: 16.10.2017]. Dostępny w WWW: <http://apcz.umk.pl/czasopisma/index. php/TSB/article/view/TSB.2016.027/11072>.

Kowalska, Małgorzata (2017). Altmetria jako przedmiot zainteresowania bibliologii i informatologii. Przeglad Biblioteczny, R. 85, nr 3, s. 324-341.

Kulczycki, Emanuel (2012). Na jakim portalu naukowiec powinien mieć konto. Warsztat bada-cza [online], [dostęp: 15.12.2018]. Dostępny w WWW: <http://ekulczycki.pl/warsztat_badacza/na-jakim-portalu-naukowiec-powinien-miec-konto/>.

Nández, Gemma; Borrego, Ángel (2013), Use of social networks for academic purposes: a case study. The Electronic Library [online], vol. 31 issue: 6 [dostęp:16.12.2018]. Dostępny w WWW: <https:/www.emeraldinsight.com/doi/abs/10.1108/EL-03-2012-0031>.

Ortega, José Luis (2017). Toward a homogenization of academic social sites: a longitudinal study of profiles in Academia.edu, Google Scholar Citations and ResearchGate. Online Information Review [online], vol. 41, issue 6 [dostęp: 14.10.2017]. Dostępny w WWW: <http://www.emeraldinsight.com/doi/abs/10.1108/OIR-01-2016-0012>.

ResearchGate (2018). About [online]. ResearchGate; [dostęp: 10.06.2018]. Dostępny w WWW: <https://www.researchgate.net/about>.

ResearchGate (2018). Help Center [online]. ResearchGate [dostęp: 10.06.2018]. Dostępny w WWW: <https://explore.researchgate.net/>.

Rodgers, Emily; Barbrow, Sarah (2014). Wskaźniki altmetryczne i ich rosnące znaczenie w bibliotekach naukowych. EBIB [online], no. 151 [dostęp: 11.01.2019]. Dostępny w WWW: <http://open.ebib.pl/ojs/index.php/ebib/article/view/249>.

Rozkosz, Ewa (2014). Serwisy społecznościowe dla naukowców (SSN) na przykładzie ResearchGate i Academia.edu. Forum Bibliotek Medycznych r. 7 nr 2 (14), s. 16-24.

Rychlik, Małgorzata (2017). Perspektywy stosowania wskaźników altmetrycznych w ocenie dorobku polskiej humanistyki. W: Kulczycki, E. (red.). Komunikacja naukowa w humanistyce. Poznań. Wydaw. Naukowe Instytutu Filozofii UAM, s. 91-111.

Sheikh, Arslan (2017). Awareness and Use of Academic Social Networking Websites by the Faculty of CIIT. Qualitative and Quantitative Methods in Libraries [online], vol. 5, no. 1 [dostęp: 23.12.2018]. Dostępny w WWW: <http://www.qqml-journal.net/index.php/ qqml/article/view/315>.

Singson, Mangkhollen; Amees, Mohammad (2017). Use of ResearchGate by the Research Scholars of Pondicherry University: A Study [online], DESIDOC Journal of Library \& Information Technology, vol. 37, no. 5 [dostęp: 23.12.2018]. Dostępny w WWW: $<$ https://www.researchgate.net/publication/322099058_Use_of_ResearchGate_by_the_ Rese-arch_Scholars_of_Pondicherry_University_A_Study>.

Stachowiak, Beata (2013). Nauczyciel akademicki a media społecznościowe [online], e-Mentor, nr 3 (50) [dostęp: 23.12.2018]. Dostępny w WWW: <http://www.e-mentor. edu.pl/mobi/artykul/index/numer/50/id/1024>.

Studzińska-Jaksim, Paulina (2011). Komunikacja naukowa, otwartość i współpraca na portalach społecznościowych. W: Otwarte zasoby wiedzy: nowe zadania uczelni i bibliotek w rozwoju komunikacji naukowej, Cracow, Zakopane (Poland), 15-17 June 2011 [online], [dostęp: 15.12.2018]. Dostępny w WWW: <http://eprints.rclis.org/17299/>. 
Taterczyńska, Marzena; Klimko, Renata; Rogowska, Edyta (2015). Profil naukowca w środowisku cyfrowym. W: Rola biblioteki akademickiej w rozwoju komunikacji naukowej, Szczecin, 11-12 czerwca 2015 [online], [dostęp: 15.12.2018]. Dostępny w WWW: $<$ https://www.researchgate.net/publication/279447602_Profil_nauko wca_w_srodowisku_cyfrowym>.

Van Noorden, Richard (2014). Online collaboration: Scientists and the social network. Nature [online], vol. 512, issue 7513 [dostęp: 13.01.2019]. Dostępny w WWW: <https://www. nature.com/news/online-collaboration-scientists-and-the-social-network-1.15711\#/corrections>.

Artykut w wersji poprawionej wptynąt do Redakcji 14 kwietnia 2019 r.

NATALIA BIAŁKA

Jagiellonian University

e-mail: natalia2.bialka@doctoral.uj.edu.pl

\section{PRESENCE OF POLISH RESEARCHERS IN THE FIELD OF INFORMATION AND BOOK STUDIES IN ACADE- MIA.EDU AND RESEARCHGATE - SOCIAL NETWOR- KING SERVICES ADDRESSED TO SCHOLARS}

KEYWORDS: Academia.edu. Information and book studies in Poland. ResearchGate. Social networking services for scholars.

ABSTRACT: Thesis/Objective - The aim of the paper is to discuss the presence of Polish researchers in the field of library and information science in two academic social networks: Academia.edu and ResearchGate and analyze the structure of this group as regards age, gender, scientific status and research interests. In the context of this study, the word 'presence' is understood as the registration of an account regardless of the form and degree of involvement in the activities within the network. Research methods - In accordance with the proposed methodology of finding accounts of Polish researchers in the field of library and information science in Academia.edu and ResearchGate networks the author of the article built a database containing data on the age, gender, scientific status and research interests of the afore-mentioned researchers. Next, quantitative methods were used to show the demographic structure of the group in question. Results and conclusions - The research results enabled the author to present the picture of a researcher in the field of library and information science as a user of academic social networks, limited with such features as age, gender, scientific status and research interests. The statistical researcher in the field of library and information science, registered in Academia.edu and ResearchGate is a woman 35 years old (and more) with a PhD degree, employed as an assistant professor, with a comparable specialization in the field of library and information science. 